Kevin Kosche

\title{
Contra proferentem und das Transparenzgebot im Common Law und Civil Law
}

Eine rechtsvergleichende, rechtshistorische und rechtsökonomische Analyse

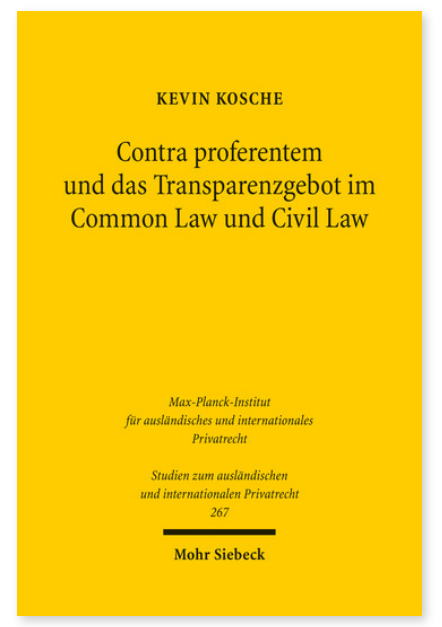

2011. XXXVI, 700 Seiten. StudIPR 267

ISBN 978-3-16-151769-3

DOI 10.1628/978-3-16-151769-3

eBook PDF 129,00€

ISBN 978-3-16-150884-4

fadengeheftete Broschur 129,00€
Kevin Kosche zeigt eine umfassende Betrachtung der rechtshistorischen Entwicklung von Contra proferentem (Unklarheitenregel) sowie des aktuellen Status quo der Auslegungsregel im anglo-amerikanischen und kontinentaleuropäischen Recht. Die Analyse von Contra proferentem im heutigen Recht ist eingebettet in eine ausführliche und bisher in der deutschen Rechtsliteratur einzigartige Beschreibung der Methode der Vertragsauslegung im englischen und US-amerikanischen Recht. Im rechtsökonomischen Teil der Arbeit untersucht der Autor die Effizienz von Contra proferentem und des Transparenzgebots als Informationspflichten und Risikoverteilungsregeln. Er schließt mit einer detaillierten rechtshistorischen und rechtsvergleichenden Analyse der Entstehung des Transparenzgebots im deutschen Recht. Der Autor legt ein bisher verborgen gebliebenes Faktum des deutschen AGB-Rechts offen: das Transparenzgebot entwickelte sich unter dem prägendem Einfluss der culpa in contrahendo und entstammt ursprünglich der versicherungsrechtlichen Rechtsprechung der 20 er und frühen 30er Jahre.

Kevin Kosche Geboren 1981; 2001-06 Studium der Politikwissenschaft, Neueren und Neuesten Geschichte und Rechtswissenschaft an der Albert-Ludwigs-Universität Freiburg; 2010 Promotion; derzeit Referendariat am Landgericht Freiburg.

Jetzt bestellen:

https://mohrsiebeck.com/buch/contra-proferentem-und-das-transparenzgebot-im-common-law-und-civil-law9783161517693?no_cache=1

order@mohrsiebeck.com

Telefon: +49 (0)7071-923-17

Telefax: $+49(0) 7071-51104$ 